2020, Volume 14, International Conference Innovative Business Management \& Global Entrepreneurship (IBMAGE 2020), pages: 01-20 | https://doi.org/10.18662/lumproc/ibmage2020/01

\section{Cooperation for Innovation: Opportunities and Challenges for SMEs (The Case of the Republic of Moldova)}

Alexandru STRATAN1,
Alexandra NOVAC ${ }^{2}$,
Natalia VINOGRADOVA

${ }^{1}$ National Institute for Economic

Research, Chisinau, Republic of Moldova, alex stratan@yahoo.com

${ }^{2}$ National Institute for Economic Research, Chisinau, Republic of Moldova, alecsandranovac@yahoo.com

3 National Institute for Economic Research, Chisinau, Republic of Moldova, natalia.vinogradova01@.gmail.com

Corresponding author
Abstract: In the contemporary economy, the sustainable growth of the competitiveness of small and medium-sized enterprises (SMEs) can be ensured provided that innovations are implemented in enterprises. The innovative potential of enterprises can be raised through various methods, including cooperation with other enterprises and researchers. The purpose of this paper is to analyze the innovation activity of SMEs in the Republic of Moldova and identify opportunities and barriers to cooperation of SMEs with other enterprises and research institutions in the Republic of Moldova in order to develop and/or implement innovations. The results of the research showed that in the Republic of Moldova, SMEs are quite reluctant and passive in cooperating with other companies and research institutions to implement innovations. Moreover, for the most part, Moldovan SMEs are not aware of the need to implement innovations based on research results, but researchers - of the need to market their results.

Keywords: Small and medium-sized enterprises (SMEs); innovation; cooperation; business environment; research environment.

How to cite: Stratan, A., Novac, A., \& Vinogradova, N. (2020). Cooperation for Innovation: Opportunities and Challenges for SMEs (The Case of the Republic of Moldova). In M. W. Staniewski, V. Vasile, \& A. Grigorescu (vol. ed.), Lumen Proceedings: Vol. 14. International Conference Innovative Business Management \& Global Entrepreneurship (IBMAGE 2020) (pp. 01-20). Iasi, Romania: LUMEN Publishing House. https://doi.org/10.18662/lumproc/ibmage2020/01 


\section{Introduction}

In the contemporary economy, the sustainable growth of the SMEs competitiveness can be ensured provided that innovations are implemented in enterprises, first of all, innovations, based on the scientific research results. These innovations have significant advantages: firstly, they make it possible to considerably improve technologies, equipment, raw materials, production organization, marketing and management in enterprises; secondly, innovations improve the image of the enterprise; thirdly, but not least, they cannot be easily reproduced by the competitors.

For the Republic of Moldova, in the conditions of signing the Deep and Comprehensive Free Trade Agreement with the EU, the increase of the competitiveness level and the implementation within the enterprises of the results of the scientific researches becomes even more important and current. In this context, the scientific and practical interest is the issues of strengthening cooperation between local entrepreneurship and researchers, first of all, the possibilities and constraints faced by both parties with the intention of implementing scientific results in enterprises.

This article examines some aspects of cooperation between small and medium-sized enterprises (SMEs) and the research environment with the aim of increasing the innovative potential of enterprises in the Republic of Moldova. The relevance of this study is due to the fact that SMEs in Moldova do not pay enough attention to the development and implementation of innovations. Entrepreneurs often do not even think about the role of innovation in improving the competitiveness of their business.

Based on interviews with entrepreneurs and representatives of research organizations, as well as representatives of intermediary institutions, the authors revealed the degree of interest of SMEs in using the results of scientific research; research directions in which SMEs are interested; existing forms of cooperation between enterprises and researchers.

The generalization of the results of the interviews allowed to identify and analyze the main opportunities and constraints faced by enterprises and researchers with the intention of SMEs to implement scientific results.

\section{Problem Statement}

A few decades ago, in-house developments were the main source of innovation in enterprises [25]. Today, only large corporations can afford to carry out expensive research on their own. However, the research required for innovative business development can rarely be carried out exclusively on the basis of laboratories of private enterprises [13]. This applies to both economically developed countries and countries in the process of 
transformation. For SMEs, the real way to increase innovation potential is to collaborate with other businesses and researchers [16].

Many of the studies indicate an increasing importance of research organizations and academia in firms' innovation activities [4]. For instance, such researchers, as Lasagni [10], Radicic et al. [17], analyzing a sample of SMEs from European countries, report that both inter-firm cooperation with suppliers and customers and cooperation with research organizations have equally significant impacts on product innovation of SMEs.

At the same time, practitioners note the existence of a number of difficulties that arise when trying to set up and to implement the cooperation between universities and SMEs, which come from the economic, behavioral, organizational characteristics of either universities and SMEs [19].

The importance of cooperation between enterprises and the research institutions/academia, which can increase the competitiveness of both individual enterprises and the economy as a whole, is highlighted in a number of EU strategic documents. So, back in 2010, a European Strategy for Smart, Sustainable and Inclusive Growth 'Europe 2020' [7] as one of the target areas of work of the European Commission and the EU member states - at the national level - as well, noted the need to promote and strengthen partnerships in the field of knowledge transfer between the fields of education (universities), research and business. The strategy of the European Commission 'Putting knowledge into practice: an expanded innovation strategy for the EU', which is aimed directly at the development of innovative activities, proposes to develop and support, inter alia, the following methods of stimulating innovation in terms of promoting cooperation between stakeholders:

- creation and development of clusters with the participation of enterprises and scientific institutions;

- improving knowledge transfer between the public research base and industry;

- creation of information networks for business, especially SMEs.

The Communication from the European Commission, Europe 2020 Flagship Initiative Innovation Union' indicates that to achieve Innovation Union, „cooperation between the worlds of science and the world of business must be enhanced, obstacles removed and incentives put in place" [8].

In European countries, public authorities at the national and/or local level use a number of instruments that directly or indirectly stimulate cooperation between SMEs and research institutions/universities. The OECD, in its review on University-Industry Collaboration (2019), identified 21 practically used policy instruments to promote university-industry 
collaboration, which can be divided into financial, regulatory and soft instruments [14].

In the Republic of Moldova, in the scientific literature, there are separately developed the issues of innovation [15; 24], and intellectual property [3; 23], on SMEs, including in various sectors of the economy [5], [2], technology transfer problems [22], as well as the development of research organizations and the scientific field in general [18].

For instance, in a recent survey (2019), carried out with the participation of the authors [9], it was mentioned that Moldovan entrepreneurs, in general, are not fully aware that the implementation of innovations can increase the competitiveness of their business. Among 70 entrepreneurs-participants of the survey, $87.1 \%$ indicated that they did not think about the necessity to implement innovation. This reflects an insufficient level of innovation culture.

However, the research gap lies in the fact that the study of the problem of cooperation between SMEs and researchers in order to develop and/or implement innovations is poorly reflected in the national scientific literature. In fact, the study from which this article is based, is the first national study in this direction. In it, on the basis of a survey of entrepreneurs, researchers, as well as representatives of intermediary institutions, the features of cooperation of key actors, as well as opportunities and constraints for cooperation in the Republic of Moldova were identified.

\section{Background: Innovations in SMEs in Moldova}

Brief data on SME sector. SMEs, with a special contribution to innovation development, play a central role in the national economies of countries around the world. For the Republic of Moldova, SMEs are, as well, a driving force for economic development. According to the data of the National Bureau of Statistics, in the Republic of Moldova in 2019, the SME sector constituted $98.6 \%$ of the total number of enterprises, employing $61.6 \%$ of the total number of employees. Of all SMEs $36.3 \%$ work in the field of trade and only $8.4 \%$ of SMEs - in the manufacturing industry, where more product and process innovations can be implemented [11].

Analysis of innovative SMEs. In the Republic of Moldova until recently it was not possible to analyze the activity of innovative SMEs due to the lack of statistical data. Starting with 2017, the National Bureau of Statistics has presented for the first time the information on the innovation activity of enterprises in the Republic of Moldova [12]. According to the National Bureau of Statistics, in the period 2017-2018, the number of 
innovative enterprises constituted 605 enterprises and represented $18 \%$ of the total number of enterprises included in the research. Distribution of enterprises by size class shows that $62.5 \%$ are small enterprises and $26.9 \%$ medium-sized enterprises. Thus, SMEs with innovation activity represented $89 \%$ of all innovative enterprises. Statistical data reflect a significant decrease in the number of innovative SMEs in the period 2017-2018 compared to the previous period 2015-2016 (by 11\%).

Typology of innovations, developed by innovative SMEs. Of the total number of innovative SMEs included in the research, 39.6\% achieved several types of innovations at the same time (of products, processes, methods of organization and marketing), 19.8\% developed product and/or process innovations, $40.7 \%$ - organizational and/or marketing methods innovation.

Ways of developing innovations by SME. Enterprises have introduced technological innovations through several ways of development and cooperation. The analyzed data show that SMEs are more focused on the independent development of innovations than on cooperation with other companies. Thus, in 2017-2018, 66\% of product innovations of SMEs have been developed independently, $16 \%$ - in cooperation with other enterprises, $10 \%$ - by adapting or modifying products developed by other enterprises, $8 \%$ - elaborated by someone else. Process innovations have been developed more often in cooperation with other firms $(21 \%)$ and by adapting or modifying products developed by other enterprises (17\%) (Figure 1).

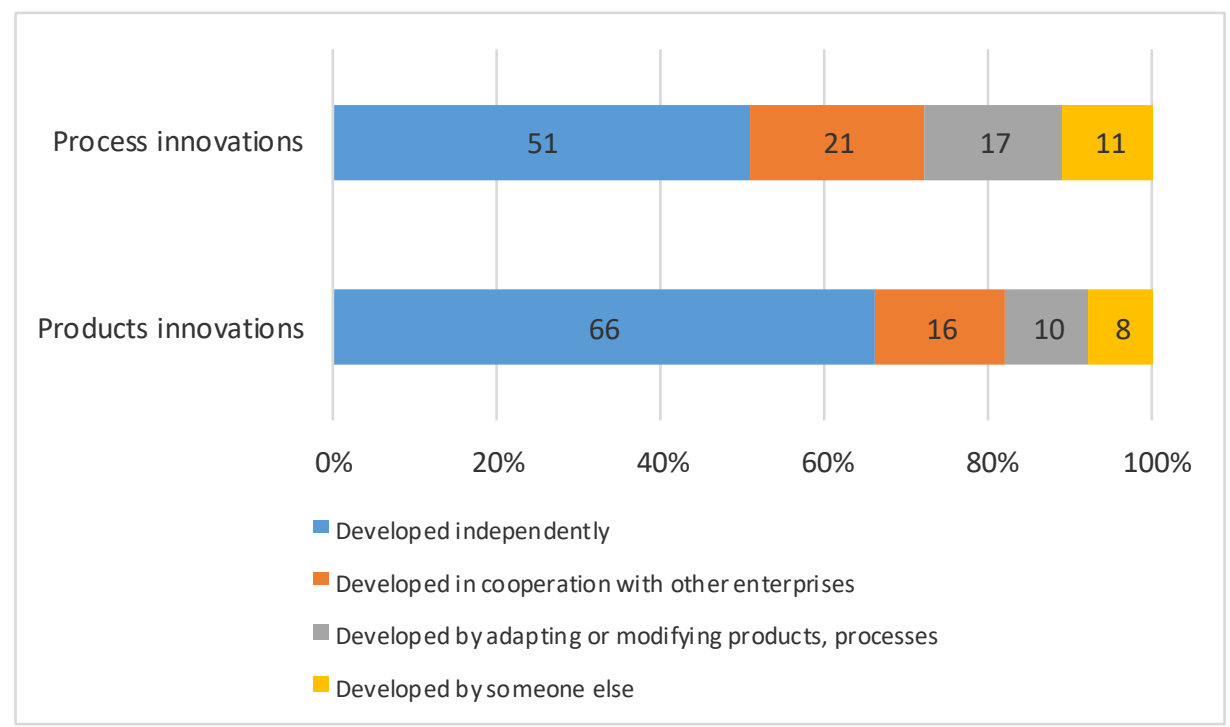

Figure 1. Ways of developing innovations by innovative enterprises Source: [12] 
Cooperation partners. The structure of technological innovative enterprises by type of cooperation is relatively uniform. Suppliers of equipment, materials, components or software (29\%) predominate as cooperation partners, followed by customers or buyers (24\%) and other enterprises (21\%). Only $6 \%$ of technological innovative enterprises indicated cooperation with universities and research institutions (Figure 2).

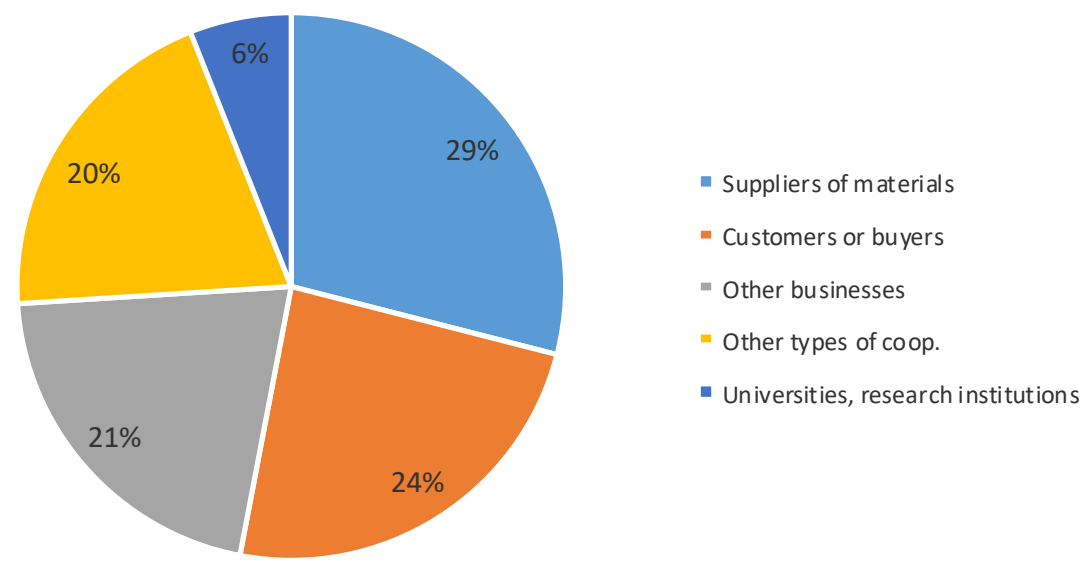

Figure 2. Type of cooperation (product and process innovation) Source: [12]

\section{The Republic of Moldova in Global Competitiveness Index and}

Global Innovation Index. A modest innovation activity of enterprises, as well as the decrease of the innovation activity in the Republic of Moldova is also reflected by the international rankings, which define the place of the countries in terms of innovation and competitiveness. In particular, the indicators reflecting the innovation activity of enterprises (business dynamism) and the innovation linkages of enterprises in the Global Competitiveness and the Global Innovation Index Reports were analyzed.

Among the important indicators, which characterize the innovation activity of enterprises, the Republic of Moldova registers less impressive positions and scores, namely the indicators: Attitude towards entrepreneurial risk (rank 80, increasing by 8 positions compared to the previous year), Growth of innovative enterprises (rank 129) and Enterprises, which embrace disruptive ideas (rank 104, worsening its place with 13 positions) [20, 21]. Unfavorable positions on these indicators indicate that for Moldavian SMEs, the innovation decision-making process is characterized by a high degree of 
complexity; there are few fast-growing innovative enterprises in the country; the Moldovan businesses show a passivity in the process of elaboration / implementation of innovations, they are still resilient to adopt completely new innovations, as for the majority of enterprises, innovation is not yet the main factor in development.

The level of cooperation is characterized by indicators, such as: cluster development, multi-stakeholder collaboration, innovation linkages. At these indicators, the Republic of Moldova ranks lower positions, worsening its place in the rankings. In particular, the level of cooperation is characterized by cluster underdevelopment (rank 136 with a score of 26.1 p.) and a weak collaboration between the scientific community and industry (rank 120), decreasing with 3 positions compared to the previous year $[6,21]$.

Table 1. The position of the Republic of Moldova in Global Competitiveness Index and Global Innovation Index

(the innovation activity and collaboration of enterprises)

\begin{tabular}{|c|c|c|c|}
\hline \multirow[t]{2}{*}{ Indicators } & \multicolumn{2}{|c|}{ The position } & \multirow[t]{2}{*}{$+/-$} \\
\hline & 2018 & 2019 & \\
\hline Global Innovation Index & 48 & 58 & -10 \\
\hline Innovation linkages & 117 & 120 & -3 \\
\hline Number of countries & 126 & 129 & \\
\hline Global Competitiveness Index & 88 & 86 & +2 \\
\hline Innovation ecosystem & 86 & 93 & -7 \\
\hline Attitudes towards entrepreneurial risk & 88 & 80 & +8 \\
\hline Growth of innovative companies & 129 & 129 & 0 \\
\hline Companies embracing disruptive ideas & 91 & 104 & -13 \\
\hline State of cluster development & 136 & 136 & 0 \\
\hline Multi-stakeholder collaboration & 117 & 120 & -3 \\
\hline Number of countries & 140 & 141 & \\
\hline
\end{tabular}

Source: based on the data of $[6,20,21]$

\section{Research Questions/Aims of the research}

As shown in the previous chapter, the partnership between the business and the academia/ researchers is at an early stage.

However, the analysis of mass-media sources shows that some actions have been taken in Moldova in recent years to strengthen the cooperation of the research environment and the business:

- elaboration and editing of specialized magazines, guides; 
- competitions for SMEs (e.g. "Best Entrepreneur in the Small and Medium Enterprises Sector" Competition. In this competition, there are several nominations, including: Best Innovative Entrepreneur),

- exhibitions, round tables, workshops, seminars, programs,

- support in promoting scientific achievements,

- co-financing of technology transfer projects, support of science and technology parks and innovation incubators;

- stimulating the creation of clusters.

Also, at the legislative level, the need to strengthen innovation in SMEs through cooperation with researchers is proclaimed. Thus, in the National Program in the fields of research and innovation for 2020-2023, among the basic principles aimed at enhancing the impact of the results of innovation and research activities on the business environment, are the following:

- strengthening cooperation between the public and private spheres, research and entrepreneurship, creating new opportunities in the market and increasing competitiveness; innovation.

- maintaining an entrepreneurial environment conducive to

One of the tasks of the National Program, named "Research and innovation for socio-economic needs", provides for launching and organizing applied projects for cooperation between the scientific community and representatives of the business environment and other activities.

But many aspects of cooperation between SMEs and researchers in order to develop and implement innovations in enterprises remain unidentified, which could serve as a basis for practical recommendations to strengthen and increase the effectiveness of such cooperation.

This article has the following objectives of the research: (i) Analysis of some aspects of the partnership between SMEs and the research environment, based especially on interviews with entrepreneurs and researchers; (ii) Identifying the opportunities and constraints in strengthening the partnership between SMEs and the research environment.

\section{Research Methods}

The data for research in the present article was obtained in the framework of several research projects carried out at the National Institute for Economic Research of Moldova in previous years [1].

In order to identify the particularities of cooperation between entrepreneurs and representatives of academia in the implementation and development of innovations in the Republic of Moldova, 46 semi-structured 
interviews were conducted. The respondents represented different groups of people: representatives of the business community, the research environment and institutions, which are interested or should be interested in promoting the idea and the process of cooperation between enterprises and research organizations. The interviewees were mostly key persons from enterprises and research organizations: directors or representatives of the management of enterprises, managers or administrators of business associations, managers of industrial parks and incubators from different development regions of the Republic of Moldova.

When arguing the choice of the research method, it was taken into account that the level of innovation activity of domestic SMEs is quite low. This conclusion has been confirmed by the results of other studies, which reflect the limited participation of domestic SMEs in the implementation of innovations. Therefore, the method of the interview was chosen (not the questionnaire), which provides for the possibility to work especially with those people who are already involved or intend to get involved in the process of implementing innovations.

\section{Findings}

The interest of SMEs in the use of scientific results. Respondents generally rated not very high the interest of domestic SMEs in cooperating with researchers and in implementing scientific achievements in enterprises. On a 5point scale, the quantitative assessment of such an interest mainly corresponded to '2' or ' 3 '. The interest of firms in use of research results largely depends on the size of the business: larger firms more frequently and systematically turn to services for research institutions, while small firms rarely do so or don't at all.

Many entrepreneurs from among the respondents have already thought about implementing innovations in their business or even tried (in fact, according to this criterion they were selected for the survey). Therefore, the own company's interest in innovations was rated quite high - with 4 or 5 points, reflecting a "high" or "very high" level of interest. However, even in this case, entrepreneurs noticed the tendency to solve problems mainly through their own efforts, without cooperation with researchers, as well as the lack of plans for companies to develop and implement scientific research, although this activity requires significant training and the existence of human and financial resources.

Because the implementation of innovations is accompanied by considerable costs, entrepreneurs calculate first the economic benefits for the enterprise and then implement, if the profit will be ensured in a short period and its amount will cover the costs, related to overcoming all "obstacles", including the corrupting element. However, there have been other cases, when 
the entrepreneur's intention to implement business innovations is not directly related to obtaining a higher profit in the near future. The entrepreneur believes that cooperation with science improves the image of his business and despite the high risk and long payback period, he is ready to invest in innovative projects.

In the interview process, the research directions in which SMEs are interested were mentioned. The list of these directions generally includes the following:

New equipment and technologies: resource and energy conservation, waste processing, biotechnology, health and biomedicine, electronics and nanotechnology, information technology, ecology and environmental protection;

- Improving product quality;

- New types of raw materials and materials;

- Management, including the implementation of information technologies in the field of management; marketing in order to increase the market share, staff training;

- $\quad$ Creating new products;

- $\quad$ Production diversification.

These needs' directions include a very wide range of issues, not only related to the production process (implementing new technologies, machinery, raw materials), but also issues related to quality growth, management and marketing. This means that the existing idea that only certain types of research can be useful to the business sphere does not fully correspond to reality.

The interest of scientific institutions in implementing their results in enterprises. The analysis of the interview results showed that the activity of scientific institutions/ universities is not sufficiently oriented on the needs of the business environment. Most research projects, currently conducted within research institutions and universities, are carried out at the expense of the state budget and their selection is made through mechanisms, conducted by public institutions.

The interest of scientists in marketing their results differs significantly depending on the sphere of research. A significantly higher interest is manifested in researchers, who deal with the improvement of technologies (production and information), mainly in the agricultural sphere and the processing industry. Another direction, required by the business sphere is the development of software products, which facilitates the cooperation of enterprises with banks, and optimizes production processes, accelerates and improves data processing, for example, accounting and depository, etc. 
Forms of cooperation between enterprises and researchers. The cooperation between enterprises and researchers is mainly realized in the following forms:

- Joint realization of innovation and technology transfer projects. These projects are currently the only form of cooperation, partly funded by the state (if the project has won the competition);

- Consultations of enterprises by researchers;

- Carrying out research at the request of enterprises;

- Purchase by the company of the scientific product;

- Cooperation of researchers and entrepreneurs, carried out within associations / consortia,

- Exhibition activity.

For the near future, it is also considered that innovation vouchers will have a positive impact.

The generalization of the results of the interviews made it possible to identify and analyze the main opportunities and constraints faced by enterprises, researchers and intermediary institutions with the intention of SMEs to implement scientific results.

The following were referred to the main opportunities for developing the partnership between enterprises and researchers with the participation of the state:

- Legislation is developed and adopted in Moldova, as well as policy documents, which regulate and promote the ideas of innovation development, on the one hand; and supporting the innovative development of SMEs - on the other hand.

- Intermediate institutions are created and operate, which already have results, although modest, but positive. First, there are institutions that perform specific functions in the process of transferring the results of research to entrepreneurs, for example, State Agency on Intellectual Property (AGEPI). Secondly, there are incubators, parks, innovation centers, created in addition to many universities for the commercialization of research results, obtained by teachers or students of those institutions.

- There is a fairly representative scientific potential. According to data of National Bureau of Statistics, the research-development activity in 2018 took place in 64 units, including 40 research institutes and centers, 17 higher education institutions and 7 - other types of units. Out of a total of units with research and development activity, 51 units or 80 percent have the form of state property. The number of employees in the research- 
development activity constituted in 2018 about 4.4 thousand people, out of which 3.0 thousand are researchers.

- The scientific environment is slowly beginning to realize the need to focus on applied scientific research, including its use in business. Such an orientation is encouraged by state funding of academic research, in which the main means are intended for applied topics.

- The possibilities of external financing for the Republic of Moldova are increasing. Moldovan researchers and entrepreneurs have had the chance to participate in European Union programs, such as Horizon-2020; the agreement on the country's participation in the COSME program was signed. The future Horizon Europe program may also be available for Moldova.

The constraints faced by business and researchers in the process of developing and implementing innovations were identified as the following:

- Insufficiency of human potential with the necessary qualifications. In enterprises, the issue of staff is particularly important and refers to different categories of staff. First, entrepreneurs themselves show low innovation and research potential. Secondly, there is insufficient training of specialists directly involved in research and innovation. Finally, there are not enough skilled workers and specialists who would be able to work on modern machines, using new technologies in production and management. Outdated equipment and technologies, currently used in many SMEs, contribute to this negative process.

- Financial constraints, which is an obstacle for all parties; businesses and scientists. To a large extent, the lack of financial resources is an obstacle for SMEs, which intend to implement innovations. Concretizing this constraint, it was observed not only the insufficiency of financial resources for SMEs, but also the extremely complicated access to borrowed and attracted resources: it is very difficult to find grants for the development of innovations, and bank loans are granted with a very high interest. For researchers, the need for financial resources depends on the specifics of their activity. The greatest need exists in those cases, where research involves expensive equipment or materials. The problem may increase in connection with the need to set up laboratories in Moldova to verify the compliance of domestic products with European standards.

- Lack of information, which could contribute to the implementation of innovations. Thus, the business sector and scientists feel the need for information at the partner search stage; they do not know who to turn to for advice on business needs or on the acquisition of certain scientific 
achievements. In addition, there is insufficient information on the possibilities of attracting financial means for innovation activity, including on external financing sources. In addition, “...businesses do not know about those programs and grants that can be obtained by collaborating with the scientific community".

- Insufficient awareness of the importance of cooperation by entrepreneurs and researchers, who are the main actors in the process of developing and implementing innovations. Representatives of SMEs do not fully understand the importance of implementing innovations, based on research results, and researchers - the need to market their results. So, the interests of the two main players in technology transfer today are not only not the same, but sometimes they do not even intersect. This reflects an insufficient level of innovative culture or even in a broad sense - entrepreneurial culture in both participants of this process.

- The complexity of finding the necessary partner, arising from those entrepreneurs and researchers who are interested in cooperation. Entrepreneurs do not know where those research results they need can be found. In turn, researchers do not have information on the needs of companies in their services. The methods currently used for this purpose (personal relationships, identification of business problems by teachers in professional retraining courses for corporate employees, etc.) cannot serve as a good basis for finding partners.

- Lack of economic incentives for scientists to initiate research, and for entrepreneurs - to implement innovations. At the same time, the experience of European states shows that there is a direct correlation between the existence of state support for innovation processes and the results obtained.

- Problems in the correlations between entrepreneurs and researchers, conditioned by a series of factors, in particular:

o Entrepreneurs' distrust of researchers. This intensifies the reluctance of entrepreneurs to address and collaborate with scientists. Entrepreneurs' distrust of scientific organizations is well-founded, as researchers characterized by conservative thinking sometimes use outdated research methods.

o Insufficient understanding by entrepreneurs of the language of exposing scientific results. The style and scientific language of researchers, operating with complicated notions are additional constraints for cooperation with the business environment.

- Insufficient orientation of researchers on the needs of the business sphere. Most of the research, currently carried out in research institutions (of state property) and universities, is carried out at the expense of the state budget 
and their selection is carried out through mechanisms, carried out by public institutions.

- Lack of knowledge and skills in most researchers in promoting personal results on the market. The character and mentality of a section of scientists, especially of the older generation, does not imply the need to deal with the commercialization of personal work results. The situation with the financing of scientific projects until recently also did not stimulate the commercialization of scientific achievements. There is an insufficiency of entrepreneurial qualities in researchers, oriented on the commercialization of the results of their work.

- High investment risk, related to the implementation of innovations, which aggravates the forecast of financial development of enterprises. In an overall unfavorable business environment, characterized by unpredictability, entrepreneurs prefer not to increase their risks.

- Complicated and expensive procedures, which must be performed by entrepreneurs in relations with intermediary institutions. E.g:

o At AGEPI the procedure for submitting applications for invention is very complicated and long. As a result, entrepreneurs are sometimes forced to spend a few months to solve this problem.

o Entrepreneurs critically evaluate the procedures regarding the preparation and evaluation of applications for technology transfer projects (complicated form of application; mandatory requirement for participation of a researcher with a scientific degree, etc.).

It is important to mention also the systemic constraints, which significantly affect the researched issue. These are, firstly, administrative barriers, which are a major burden for entrepreneurs in solving current problems related to the implementation of legislative provisions. Second, the high level of corruption and "nepotism" within the public authority bodies, as a result of which some companies gain unfair competitive advantages. Entrepreneurs also noted a large influx of active people, mainly young people, abroad, which could have been a source for the development of innovations.

\section{Discussions}

The features of cooperation between enterprises and researchers identified in the course of the research, as well as the opportunities and constraints identified in the interviews, can serve as a basis for developing recommendations to remove barriers. The recommendations are developed for all actors in the process of implementing innovations in SMEs: for the Government, business community and scientific organizations. 
The Government, in order to improve the process of implementing research results in SMEs, could provide the following measures:

- Elaboration of the special state program, oriented on the innovative development of SMEs and destined, first of all, for the development of the necessary knowledge for entrepreneurs and researchers. For these purposes, one can try to attract European funds, taking into account that the implementation of innovations, the SMEs support and the entrepreneurship education are priorities in the EU.

- Providing incentives for enterprises that implement innovations. These could be fiscal facilities (for example, not taxing part of the income), aimed at carrying out scientific research or carrying out innovative projects. Preferential loans are possible for companies that want to implement a scientific result (at different stages: research, testing, prototyping, implementation).

- Promoting the introduction in the socio-economic development programs of the districts of a separate compartment regarding the innovative development, and in perspective - the elaboration of the special local or regional programs of innovative development. The first attempts to prepare such documents are already in place.

- Allocating the budgetary means for the elaboration of innovative products/ services for the public sector (especially the services of IT companies) only on the basis of open tenders, at the same time giving priority to local enterprises.

- Wide promotion in society, first of all, in the scientific and business community, of the need to implement innovations, based on the results of scientific research.

With regard to the scientific community, the Government could provide the following:

- Development of a mechanism for identifying the needs of entrepreneurs in scientific research. Proposals must come from central and sectoral ministries, including, based on a survey of entrepreneurs.

- Monitoring the results of the scientific projects, financed from the state budget in the interests of the business sphere, by means of the Ministry of Economy and Infrastructure jointly with the sectoral ministries and the representatives of the business community.

- Initiation by the Ministry of Education, Culture and Research of changes in the structure of educational courses, especially: 
o When training students in the disciplines "Management" and "Basics of Entrepreneurship" to intensify the attention on the topic, related to the implementation of innovations in enterprises, especially innovation management and marketing, technological audit, etc.

- To cultivate in entrepreneurs, first of all, within the courses, organized by the Organization for SME Development from the account of budgetary resources, of the competences of innovation management.

- To cultivate in young researchers in doctoral studies the entrepreneurial and marketing skills for product promotion.

The business community can contribute to the development of innovation businesses, based on research results, by lobbying the provision of facilities to enterprises that implement innovations.

Scientific organizations, in order to facilitate the process of implementing scientific results in SMEs, could take the following measures:

- Changing the research vector, intensifying the emphasis on applied research, at the same time, focusing more on the needs of enterprises.

- Improving the quality of research, focusing on the tasks, topics and methods used in the most developed scientific centers in the world, adapting them to the current conditions of the Republic of Moldova.

- Cultivating the skills and abilities of entrepreneurial activity in researchers.

- Promoting the importance of focusing research on the needs of enterprises not only of certain scientists, but, first of all, of institutions or groups of researchers, focused on a certain sphere of activity.

\section{Conclusions}

In the Republic of Moldova, the innovation capacity of enterprises and, in particular, the participation of the private sector in research-developmentinnovation activities continues to be insignificant. Business sector innovation in industry and services is largely based on procurement of foreign equipment and technology, and is characterized by a low level of cooperation with the research environment. There is also a lack of qualified staff, such as engineers, technologists, programmers, etc., which is a rather serious obstacle in the 
development and implementation of innovations (a fact demonstrated over the years by the interviews and surveys with entrepreneurs).

Peculiarities of the partnership between SMEs and the research environment in the Republic of Moldova are characterized by the following:

- Quite low interest of domestic SMEs in cooperating with researchers and in implementing scientific achievements in enterprises.

- $\quad$ Research directions in which SMEs are interested include a very wide range of issues, not only related to the production process (implementing new technologies, machinery, raw materials), but also issues related to quality growth, management and marketing.

- The activity of scientific institutions/ universities is not sufficiently oriented on the needs of the business environment.

- Forms of cooperation between companies and researchers include mainly short-term, one-time actions, such as, for example, carrying out research at the request of enterprises, consultations, exhibition activity, etc.

The main opportunities for developing the partnership between enterprises and researchers with the participation of the state include the following: in Moldova.

Legislation and policy documents are developed and adopted

- Intermediate institutions are created and function, which already have results, although modest, but positive.

- There is a fairly representative scientific potential.

- The scientific environment, though slowly, but begins to realize the need for applied scientific research, including their use in business.

- In the business community, some entrepreneurs understand the need to implement innovations, the importance of using the results of science for business development.

- The possibilities of external financing for the Republic of Moldova are increasing, Moldovan researchers and entrepreneurs have the chance to participate in European Union programs.

The constraints faced by the participants in the technology transfer process were identified and analyzed: the insufficiency of the elaboration of the legislative and regulatory framework; difficulties in finding workers with the necessary qualifications; insufficient financial possibilities, which is an obstacle for all parties: enterprises, scientists and intermediaries; lack of information, which could contribute to the implementation of innovations; insufficient 
awareness of the importance of cooperation by entrepreneurs and researchers, who are the main actors in the process of developing and implementing innovations; the complexity of finding the necessary partner, appeared to those entrepreneurs and researchers, who are interested in cooperation; lack of economic incentives for scientists to initiate research, and for entrepreneurs - to implement innovations; problems in the correlations between entrepreneurs and researchers, conditioned by a series of factors; lack of knowledge and skills of most researchers in promoting personal results on the market; high investment risk, related to the implementation of innovations; complicated and expensive procedures, which must be performed by entrepreneurs in relations with intermediary institutions; lack of a constructive dialogue between enterprises, intermediate institutions and public authorities.

\section{References}

[1] Aculai E, Vinogradova N, Novac A, Percinschi N, Maier L, et al. Analiza posibilităţilor şi constrângerilor în consolidarea parteneriatului dintre IMM-uri, instituţiile publice şi mediul de cercetare în vederea creşterii competitivității afacerilor. Chisinau: INCE; 2014. 209 p. Raport: 11.817.08.29A

[2] Amarfii-Railean N. Dezvoltarea inovationala a industriei agroalimentare in epoca digitala. Academos. 2020;2:75-80.

[3] Badâr I. Proprietatea intelectuală în sprijinul întreprinderilor mici si mijlocii. Intellectus. 2013;1:38-45.

[4] Davey T, Meerman A, Galan Muros V, Orazbayeva B, Baaken T. The State of University-Business Cooperation in Europe. Final Report. European Commission, Luxembourg: Publications Office of the European Union. 2018. $179 \mathrm{p}$.

[5] Dombrovschi I. Implementarea tehnologiilor inovaționale - premisă a eficientizării producției agricole. Economica. 2020;1(111):34-50.

[6] Dutta S, Lanvin B, Wunsch-Vincent S. editors. The Global Innovation Index 2019: Creating Healthy Lives - The Future of Medical Innovation. Ithaca, Fontainebleau, and Geneva: Cornell University, INSEAD, and WIPO; 2019. 451 p. [cited 2020 Sep 08]. Available from: https://www.wipo.int/edocs/pubdocs/en/wipo_pub_gii_2019.pdf

[7] European Commission. Europe 2020: A European strategy for smart, sustainable and inclusive growth. Brussels; 2010. 32 p.

[8] European Commission. Europe 2020: Flagship Initiative 'Innovation Union'. EU: Directorate-General for Research and Innovation; 2011. 43 p.

[9] Institutul Economiei de Piata. Raport intermediar cu privire la evaluarea documentelor de politici economice, care vizează mediul de afaceri. Chisinau: Institutul Economiei de Piata; 2019. 231 p. 
[10] Lasagni A. How Can External Relationships Enhance Innovation in SMEs? New Evidence for Europe. JSBM. 2012 April;50(2):310-339.

[11] National Bureau of Statistics of the Republic of Moldova. Activitatea întreprinderilor mici şi mijlocii în Republica Moldova în anul 2019. [Internet]. Chisinau: National Bureau of Statistics of the Republic of Moldova; 2019 [cited 2020 Sep 08]. Available from: https://statistica.gov.md/newsview.php?l=ro\&idc $=168 \&$ id $=6716$

[12] National Bureau of Statistics of the Republic of Moldova. Rezultatele activitătii de inovare a întreprinderilor în Republica Moldova în anii 2017-2018 [Internet]. Chisinau: National Bureau of Statistics of the Republic of Moldova; 2019 [cited 2020 Sep 08]. Available from: https:// statistica.gov.md/newsview.php?l=ro\&idc=168\&id=6541

[13] Nelson R. The Market Economy, and the scientific commons. Research Policy. 2004;33:455-471.

[14] OECD. University-Industry Collaboration: New evidence and policy options. [Internet]. Paris: OECD Publishing; 2019 [cited 2020 Sep 08]. Available from: https://read.oecd-ilibrary.org/science-and-technology/university-industrycollaboration_e9c1e648-en\#page13

[15] Pârțachi I, Luțcan A. Inovația - succesul unei afaceri. Economica. 2009; 2(66):65-75.

[16] Peças P, Henriques E. Best practices of collaboration between university and industrial SMEs. Benchmarking: An Intern J. 2006;13(1/2):54-67.

[17] Radicic D, Pugh G, Douglas D. Promoting cooperation in innovation ecosystems: evidence from European traditional manufacturing SMEs. Small Bus Econ. 2020;54:257-283

[18] Rotaru A, Cuciureanu G. Cooperarea internationala - factor esential in stiinta moderna. Intellectus. 2004;4:14-21.

[19] Roveda C. Critical issues of the cooperation for innovation between universities and SMEs. RAEX Rating Rev [Internet]. Date of publication 2020 08 [cited 2020 Aug 26]. Available from: https://raexrr.com/third_mission_project/experts_articles/universities_and_business

[20] Schwab K. editor. The Global Competitiveness Report 2018. Geneva: World Economic Forum; 2018. 671 p. [cited 2020 Sep 08]. Available from: http://www3.weforum.org/docs/GCR2018/05FullReport/TheGlobalCompe titivenessReport2018.pdf

[21] Schwab K. editor. The Global Competitiveness Report 2019. Geneva: World Economic Forum; 2019. 666 p. [cited 2020 Sep 08]. Available from: http://www3.weforum.org/docs/WEF_TheGlobalCompetitivenessReport20 19.pdf

[22] Soroceanu I. Mecanisme de incurajare a inovatiilor si transferului tehnologic. Intellectus. 2019;1-2:78-83. 
[23] Stratan A, Novac A. Indicators system for monitoring intellectual property management in companies. Economy and sociology. 2017;3:12-19.

[24] Stratan A, Novac A, Maier L. Inovarea ca factor de dezvoltare a IMM-urilor din Republica Moldova. Intellectus. 2018;2:58-68.

[25] Yoo HS, Lee C, Jun S-P. The Characteristics of SMEs Preferring Cooperative Research and Development Support from the Government: The Case of Korea. MDPI Sustainability. 2018 Aug.;10: 3048. 